\title{
Aberrant methylation of SPARC in human lung cancers
}

\section{Suzuki*, I,2, C Hao'2, T Takahashi', H Shigematsu', N Shivapurkar', UG Sathyanarayana', T lizasa ${ }^{2}$, T Fujisawa $^{2}$, K Hiroshima ${ }^{3}$ and AF Gazdar}

'Hamon Center for Therapeutic Oncology Research, Department of Pathology, University of Texas Southwestern Medical Center, Dallas, TX 75390, USA;

${ }^{2}$ Department of Thoracic Surgery, Graduate School of Medicine, Chiba University, Chiba 260-8607, Japan; ${ }^{3}$ Department of Basic Pathology, Graduate School of Medicine, Chiba University, Chiba 260-8607, Japan

SPARC (secreted protein acidic and rich in cysteine) is an extracellular $\mathrm{Ca}^{2+}$-binding matricellular glycoprotein associated with the regulation of cell adhesion and growth. We investigated loss of expression of SPARC gene and promoter methylation in lung cancers and correlated the data with clinicopathological features. We observed loss of SPARC expression in 12 of 20 (60\%) lung cancer cell lines. Treatment of expression-negative cell lines with a demethylating agent restored expression in all cases. Methylation frequencies of SPARC gene were 55\% in 20 lung cancer cell lines. Primary tumours had methylation at a rate of 69\% (119 of 173), while nonmalignant lung tissues $(n=60)$ had very low rates $(3 \%)$. In lung adenocarcinomas, SPARC methylation correlated with a negative prognosis $(P=0.0021$; relative risk 4.65 , 95\% confidence interval $1.75-12.35$, multivariate Cox's proportional-hazard model). Immunostaining revealed protein expression in bronchial epithelium (weak intensity) and in juxtatumoral stromal tissues (strong intensity) accompanied by frequent loss in cancer cells that correlated with the presence of methylation $(P<0.00 \mathrm{I})$. Our findings are of biological interest and potentially of clinical importance in human lung cancers.

British Journal of Cancer (2005) 92, 942-948. doi:I0.1038/sj.bjc.6602376 www.bjcancer.com

Published online I March 2005

(c) 2005 Cancer Research UK

Keywords: methylation; SPARC; lung cancer; immunostaining

The matricellular protein SPARC (secreted protein acidic and rich in cysteine), also known as osteonectin/BM-40, is a calciumbinding glycoprotein that shows a high degree of interspecies sequence conservation and plays an important role in cell-matrix interactions during tissue remodelling, wound repair, morphogenesis, cellular differentiation, cell migration, and angiogenesis (Sage et al, 1989; Jendraschak and Sage, 1996; Yan and Sage, 1999; Bradshaw and Sage, 2001; Brekken and Sage, 2001). Its role in tumorigenesis is complex, and expression is often being downregulated in tumour cells accompanied by upregulation in juxtatumoral stromal cells. $S P A R C$ is highly expressed in reactive fibroblasts, and expression is deregulated in many types of human malignant tumours (Porte et al, 1995; Le Bail et al, 1999; Rempel et al, 1999; Paley et al, 2000). SPARC may promote vascularisation of tumours, tumour progression, or invasiveness by modulating the activity of cytokines and stimulating secretion of tissue remodelling metalloproteases (Lane and Sage, 1994; Motamed and Sage, 1997; Sage, 1997). Owing to the correlation between expression and invasion, SPARC was thought to be a proinvasive protein (Everitt and Sage, 1992a, b; Lane et al, 1994; Ledda et al, 1997). However, ovarian cancer cells treated with SPARC showed inhibition of cell proliferation and underwent apoptosis (Yiu et al, 2001). SPARC potently inhibited angiogenesis

*Correspondence: Dr M Suzuki, Department of Thoracic Surgery, Graduate School of Medicine, Chiba University, I-8-I Inohana, Chuo-ku, Chiba 260-8670, Japan; E-mail: smakoto@chiba-cc.jp

Received 16 August 2004; revised 24 November 2004; accepted 9 December 2004; published online I March 2005 and significantly impaired neuroblastoma tumour growth in vivo (Chlenski et al, 2002). Implanted Lewis lung carcinoma cells grew more rapidly in SPARC null mice (Brekken et al, 2003). Thus, the exact role of SPARC in tumour growth and progression is unclear.

DNA methylation is a major mechanism associated with the inactivation of tumour suppressor genes in cancer (Esteller et al, 2001; Jones and Baylin, 2002; Suzuki et al, 2004). It has been reported that $S P A R C$ is silenced through DNA methylation in pancreatic cancer cells (Sato et al, 2003). SPARC protein by immunostaining was overexpressed in stromal fibroblasts immediately adjacent to the neoplastic epithelium in pancreatic cancers, suggesting SPARC expression in juxtatumoral tissues is regulated through tumour-stromal interactions (Sato et al, 2003). As exogenous SPARC inhibits the growth of pancreatic cancer cells in vitro, tumour-stromal interactions of SPARC may act to facilitate or retard tumour progression (Sato et al, 2003).

In non-small-cell lung cancer (NSCLC), SPARC expression by immunostaining was also found strongly in stromal fibroblasts, persistently in chondrocytes of bronchial cartilage, weakly in bronchial epithelium, but not in alveolar cells nor in tumour cells (Koukourakis et al, 2003). SPARC, is located at 5q33.1, a region that demonstrates frequent loss of heterozygosity in idiopathic pulmonary fibrosis and small-cell lung cancer (SCLC) (Girard et al, 2000; Demopoulos et al, 2002).

In this study, we examined the mRNA expression and methylation of SPARC in lung cancer cell lines, and examined the methylation and protein by immunostaining in primary tumours. We correlated these findings with clinicopathologic features. 


\section{MATERIALS AND METHODS}

\section{Cell lines and tumour samples}

We studied 12 NSCLC cell lines (NCI-H460, NCI-H1437, NCIH1770, NCI-H2087, NCI-H2122, NCI-H2126, HCC15, HCC95, HCC193, HCC366, HCC515, HCC1171) and eight SCLC cell lines (NCI-H69， NCI-H146， NCI-H209， NCI-H211，NCI-H524， NCIH526, NCI-H1672, NCI-H2171) that were established by us (Phelps et al, 1996), several of which are deposited in the American Type Culture Collection (Manassas, VA, USA). Cell cultures were grown in RPMI-1640 medium (Life Technologies Inc., Rockville, MD, USA) supplemented with $5 \%$ fetal bovine serum and incubated in $5 \% \mathrm{CO}_{2}$ at $37^{\circ} \mathrm{C}$. Cell lines established at the National Cancer Institute have the prefix NCI, while those established at UT Southwestern Medical Center have the prefix HCC. Nonmalignant human bronchial epithelial cells (NHBEC) were cultured as reported previously (Toyooka et al, 2002), and normal trachea RNA was obtained from Clontech (Palo Alto, CA, USA).

Surgically resected samples were obtained from patients with lung cancer who had not received treatment prior to resection at the Chiba University Hospital, Japan, after obtaining Institutional Review Board approval and informed consent. Samples were immediately frozen and stored at $-80^{\circ} \mathrm{C}$ until used.

\section{Reverse transcription - polymerase chain reaction (RT - PCR) assay}

An RT - PCR assay was used to examine SPARC mRNA expression. Total RNA was extracted from the samples with Trizol (Life Technologies, Rockville, MD, USA) following the manufacturer's instructions. RT reaction was performed on $4 \mu \mathrm{g}$ total RNA with deoxyribonuclease I and the SuperScript II First-Strand Synthesis using oligo-(dT) primer System (Life Technologies), and aliquots of the reaction mixture were used for the subsequent PCR amplification. The forward PCR amplification primer of SPARC was $5^{\prime}$-AAGATCCATGAGAATGAGAAG- $3^{\prime}$ (Ex8-S), and the reverse primer $5^{\prime}$-AAAAGCGGGTGGTGCAATG-3' (Ex9-AS) (Accession number NM_003118; forward, nucleotides 649-669; reverse, nucleotides $847-865)$. These sequences are separated by an intron, and we confirmed that genomic DNA was not amplified with these primers. Polymerase chain reaction amplification was carried out for $12 \mathrm{~min}$ at $95^{\circ} \mathrm{C}$ for initial denaturation, followed by 33 cycles of $94^{\circ} \mathrm{C}$ for $30 \mathrm{~s}, 60^{\circ} \mathrm{C}$ for $30 \mathrm{~s}$, and $72^{\circ} \mathrm{C}$ for $45 \mathrm{~s}$. The housekeeping gene GAPDH (glyceraldehyde-3-phosphate dehydrogenase) was used as an internal control to confirm the success of the RT reaction. The primers for GAPDH amplification were as follows: forward primer, 5'-CACTGGCGTCTTCACCACCATG-3'; and reverse primer, $5^{\prime}$-GCTTCACCACCTTCTTGATGTCA- $3^{\prime}$. Polymerase chain reaction amplification was carried out for $12 \mathrm{~min}$ at $95^{\circ} \mathrm{C}$ for initial denaturation, followed by 25 cycles of $94^{\circ} \mathrm{C}$ for $30 \mathrm{~s}, 65^{\circ} \mathrm{C}$ for $45 \mathrm{~s}$, and $72^{\circ} \mathrm{C}$ for $30 \mathrm{~s}$. These primer sequences were identical to the human target genes as confirmed by a BLAST search. Polymerase chain reaction products were analysed on $2 \%$ agarose gels. Nonmalignant human bronchial and normal trachea were used as normal controls for RT-PCR.

\section{5-Aza-2'-deoxycytidine (5-Aza-CdR) treatment}

In all, 11 tumour cell lines with SPARC hypermethylation and absent gene expression were incubated in culture medium with $4 \mu \mathrm{m} 5$-Aza-CdR for 6 days, with medium changes on days 1,3 , and 5. The cells were harvested and RNA was extracted at day 6 .

\section{DNA extraction and methylation-specific PCR (MSP)}

Genomic DNA was obtained from cell lines, cultured nonmalignant cells, primary tumours, and nonmalignant tissues by digestion with proteinase $\mathrm{K}$ (Life Technologies), followed by phenol/chloroform (1:1) extraction (Herrmann and Frischauf, 1987). DNA methylation patterns in the CpG island of SPARC were determined by the method of MSP as reported by Herman et al (1996). Primer sequences of SPARC for unmethyalted reaction were $5^{\prime}$-TTTTTTAGATTGTTTGGAGAGTG-3' (sense) and 5'-AACTAACAACATAAACAAAAATATC- $3^{\prime}$ (antisense), and for the methylated reaction, 5'-GAGAGCGCGTTTTGTTTGTC-3' (sense) and 5'-AACGACGTAAACGAAAATATCG-3' (antisense) (Sato et al, 2003). Briefly, $1 \mu \mathrm{g}$ of genomic DNA was denatured by $\mathrm{NaOH}$ and modified by bisulfite. The modified DNA was purified using Wizard DNA purification kit (Promega, Madison, WI, USA), treated with $\mathrm{NaOH}$ to desulphonate, precipitated with ethanol, and resuspended in water. Polymerase chain reaction amplification was carried out for $12 \mathrm{~min}$ at $95^{\circ} \mathrm{C}$ for initial denaturation, followed by 38 cycles of $94^{\circ} \mathrm{C}$ for $20 \mathrm{~s}, 62^{\circ} \mathrm{C}$ for $20 \mathrm{~s}$, and $72^{\circ} \mathrm{C}$ for $30 \mathrm{~s}$. DNA from peripheral blood lymphocytes $(n=14)$ from healthy nonsmoking subjects was used as negative controls for methylationspecific assays. DNA from lymphocytes of a healthy volunteer treated with Sss1 methyltransferase (New England BioLabs, Beverly, MA, USA) and then subjected to bisulfite treatment was used as a positive control for methylated alleles. Water blanks were included with each assay. Polymerase chain reaction products were visualised on $2 \%$ agarose gels stained with ethidium bromide.

\section{Immunostaining}

SPARC was detected on paraffin-embedded tissue sections by the avidin-biotin peroxidase complex method using a mouse monoclonal antibody generated against the $\mathrm{N}$-terminal region of SPARC (AON-5031; Hematologic Technologies Inc., Essex Junction, VT, USA). After immunostaining, the sections were counterstained with haematoxylin, dehydrated, and mounted.

Immunostaining was graded by two independent observers unaware of clinical or laboratory findings. Staining was categorised from 0 to $4+$ based on the percentage of cells stained. Score 0 was assigned if less than $5 \%$ of cells were positive. A weak staining $(+1)$ was assigned if $6-25 \%$ of cells were positive, a moderate staining $(2+)$ was assigned if $26-50 \%$ of cells were positive, high sore $(3+)$ was assigned if $51-75 \%$ of cells were positive, and a very high score $(+4)$ was assigned if more than $75 \%$ of cells stained positive. The degree of staining intensity was also noted.

\section{Statistical analysis}

Statistical differences between groups were examined using Fisher's exact test, $\chi^{2}$ test, and Mann-Whitney test. Survival was calculated from the date of initial diagnosis until death or the date of the last follow-up (censored). Survival was analysed according to the Kaplan-Meier method, and differences in their distribution were evaluated by means of the log-rank test. A multivariate Cox's proportional-hazard model was developed to evaluate the covariates' joint effects. All $P$ 's are two-sided, and $P$ of less than 0.05 was defined as being statistically significant.

\section{RESULTS}

\section{Aberrant methylation and expression of SPARC in cell lines}

Expression of SPARC was examined by RT - PCR, and representative examples are shown in Figure 1A. SPARC expression was present in NHBEC and normal trachea. However, loss of SPARC expression was observed in 10 of 12 (83\%) NSCLC cell lines, and two of eight (25\%) SCLC cell lines (Table 1 and Figure 1B). Aberrant methylation was absent in DNA from peripheral blood lymphocytes from healthy nonsmoking volunteers $(n=14)$ and NHBEC. Aberrant methylation was found in nine of $12(75 \%)$ 


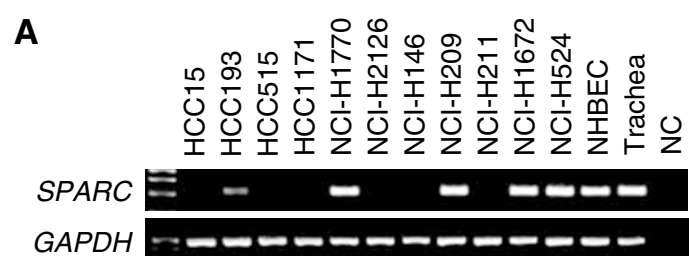

B
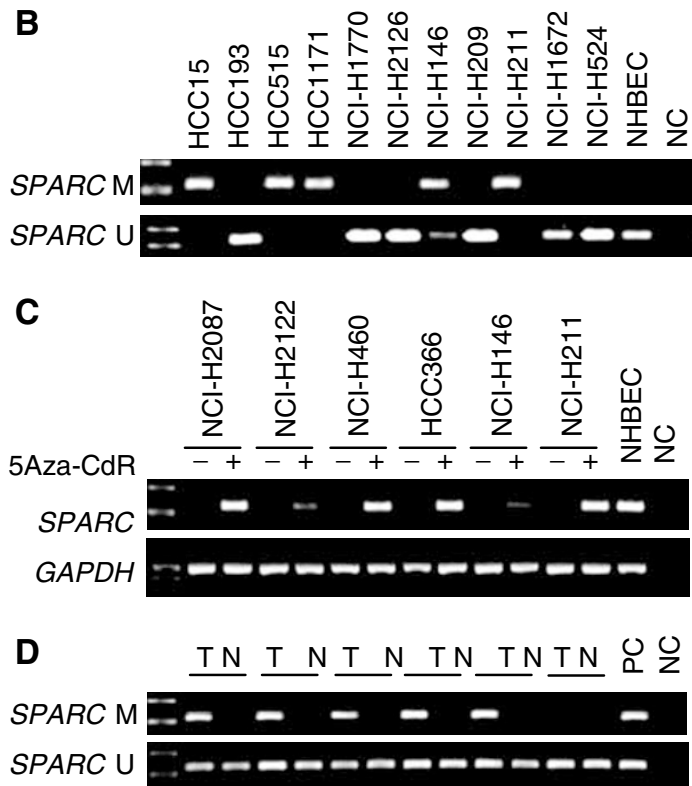

Figure I (A) Representative examples of RT-PCR for SPARC in lung cancer cell lines, NHBEC, and normal trachea. GAPDH was used as a control for the RNA integrity and RT reactions. NC= negative control. (B) Representative examples of MSP assay in cell lines. Polymerase chain reaction products were visualised on $2 \%$ agarose gels stained with ethidium bromide. $M=$ methylated band; $U=$ unmethylated band. (C) Representative examples of RT-PCR for SPARC mRNA in lung cancer cell lines before $(-)$ and after $(+)$ treatment with 5-Aza-CdR. (D) Representative examples of MSP assay in primary tumours and nonmalignant tissues. All PCR products were visualised on $2 \%$ agarose gels stained with ethidium bromide. $M=$ methylated band; $U=$ unmethylated band; $T=$ lung cancer tissues; $\mathrm{N}=$ nonmalignant lung tissue; $\mathrm{PC}=$ positive control.

NSCLC cell lines, and two of eight (25\%) SCLC cell lines. Both loss of expression and lack of methylation of SPARC were found in NSCLC cell line NCI-H2126, suggesting an alterative method of gene silencing in this cell line. The concordance between loss of gene expression and aberrant methylation of SPARC was $92 \%$ in NSCLC cell lines, and 100\% in SCLC cell lines (overall concordance 95\%).

\section{5-Aza-2'-deoxycytidine treatment}

Nine NSCLC cell lines (NCI-H460, NCI-H1437, NCI-H2087, NCIH2122, HCC15, HCC95, HCC366, HCC515, HCC1171) and two SCLC cell lines (NCI-H146, NCI-H211) that showed loss of expression and methylation of SPARC were cultured with the demethylating agent 5-Aza-CdR. SPARC expression was restored after treatment in all 11 methylated cell lines tested (Figure 1C).

\section{Aberrant methylation of $S P A R C$ in primary tumours}

Results of aberrant methylation of SPARC in primary tumours and nonmalignant tissues are detailed in Table 1 and Figure 1D. SPARC methylation was a tumour-specific event in lung cancers
Table I SPARC methylation in lung cancers

\begin{tabular}{lcc}
\hline Samples & Total no. & No. methylated (\%) \\
\hline Tumours & 193 & \\
$\quad$ Cell lines & 12 & $9(75)$ \\
$\quad$ NSCLC cell lines & 8 & $2(25)$ \\
$\quad$ SCLC cell lines & & \\
Primary NSCLC & 84 & $57(68)$ \\
$\quad$ Adenocarcinoma & 61 & $52(85)$ \\
$\quad$ Squamous cell carcinoma & 11 & $6(55)$ \\
$\quad$ Large-cell carcinoma & 5 & $0(0)$ \\
Others & 12 & $4(33)$ \\
Primary SCLC & 74 & \\
Nonmalignant & 60 & $2(3)$ \\
Lung tissues and NHBEC & 14 & $0(0)$ \\
Peripheral blood mononuclear cells & \\
\hline
\end{tabular}

NSCLC = non-small-cell lung cancer; $\quad \mathrm{SCLC}=$ small-cell lung cancer, $\mathrm{NHBEC}=$ nonmalignant human bronchial epithelial cells. ${ }^{\mathrm{a}}$ From healthy nonsmoking volunteers.
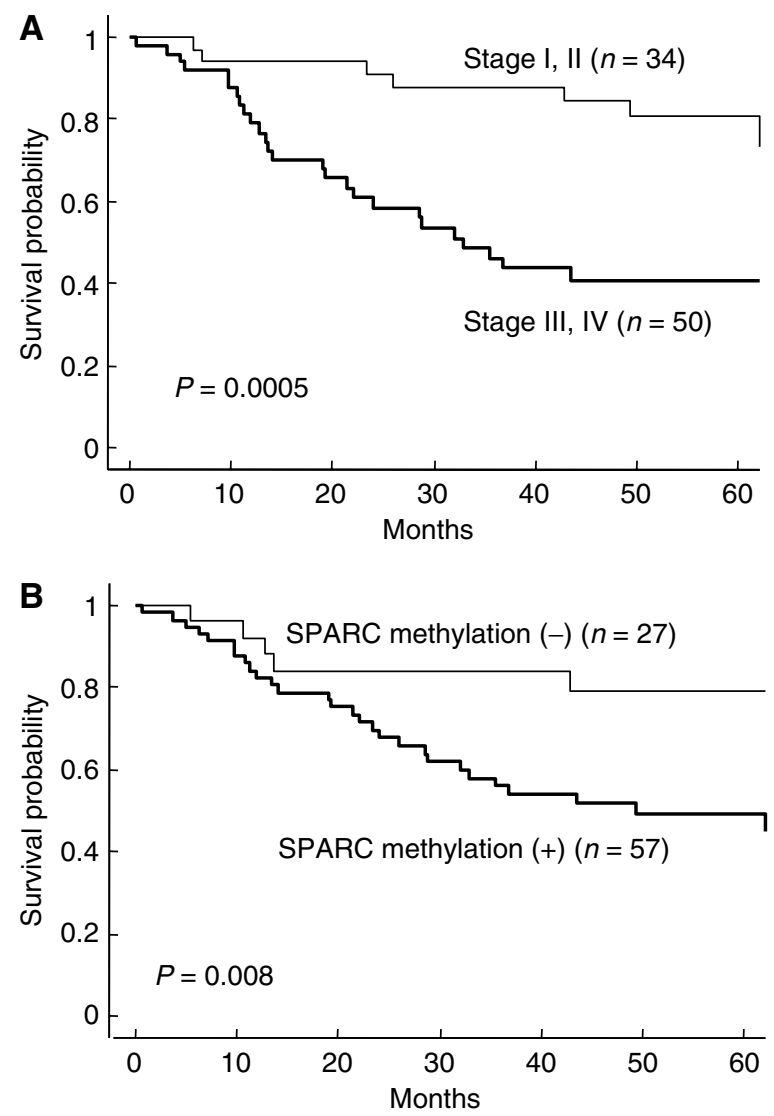

Figure 2 Overall survival for 84 lung adenocarcinoma patients with early stages $(n=34)$ or advanced stages $(n=50)(\mathbf{A})$, or with $(n=57)$ or without $(n=27)$ the methylation of SPARC (B). Probability of survival curves was calculated using the Kaplan-Meier product-limit method and compared via the log-rank test between groups.

$(P=0.0001)$ when compared with corresponding adjacent nonmalignant tissues.

Of 173 lung cancers, 119 (69\%) were found to be methylated. There was a significant relationship between the major histologic types of lung cancer, NSCLC (115 of 161, 71\%) and SCLC (four of 
Table 2 Univariate and multivariate statistics of the prognostic value of gender, age, smoking, stage, and methylation status of SPARC for survival in lung adenocarcinomas

\begin{tabular}{|c|c|c|c|c|c|}
\hline & \multirow[b]{2}{*}{ Number } & \multirow{2}{*}{$\begin{array}{c}\text { Univariate } \\
P \text {-value }\end{array}$} & \multicolumn{3}{|c|}{ Multivariate } \\
\hline & & & Risk ratio & $95 \% \mathrm{Cl}$ & $P$-value \\
\hline \multicolumn{6}{|l|}{ Gender } \\
\hline Female & 40 & 0.76 & 0.71 & $0.30-1.65$ & 0.42 \\
\hline Male & 44 & & & & \\
\hline \multicolumn{6}{|l|}{ Age (years) } \\
\hline$<64^{\mathrm{a}}$ & 42 & 0.58 & 1.73 & $0.87-3.42$ & 0.12 \\
\hline$>64$ & 42 & & & & \\
\hline \multicolumn{6}{|l|}{ Smoking } \\
\hline Nonsmoker & 39 & 0.43 & 1.52 & $0.65-3.57$ & 0.34 \\
\hline Smoker & 45 & & & & \\
\hline \multicolumn{6}{|l|}{ Stage } \\
\hline |, || & 34 & 0.0005 & 4.44 & $1.98-9.90$ & 0.0003 \\
\hline III, IV & 50 & & & & \\
\hline \multicolumn{6}{|c|}{ SPARC methylation } \\
\hline- & 27 & 0.008 & 4.65 & $1.75-12.35$ & 0.0021 \\
\hline+ & 57 & & & & \\
\hline
\end{tabular}

Results of univariate analyses using the log-rank test and multivariate analyses using Cox's proportional-hazard model of prognostic factors for overall survival. Stage and SPARC methylation are significantly associated with poor survival. $\mathrm{Cl}=$ confidence interval; SPARC = secreted protein acidic and rich in cysteine. ${ }^{2}$ Divided by median age of adenocarcinoma cases.
$12,33 \%)(P=0.01)$. When compared with clinicopathologic data, there was no significant association with gender, age, smoking history, or tumour stage. However, the frequency of methylation was significantly higher in squamous cell carcinomas (52 of 61, $85 \%)$ compared to adenocarcinomas (57 of $84,68 \%)(P=0.01)$. Overall survival of adenocarcinomas was poorer in patients with $S P A R C$ methylation than in those without methylation $(P=0.008$; log-rank test; Figure 2) and for patients with advanced stages $(P=0.0005)$. In a multivariate Cox's proportional-hazard model, promoter methylation of SPARC was an independent adverse prognostic factor $(P=0.0021$; relative risk (RR) $4.65,95 \%$ confidence interval (CI) $1.75-12.35)$ next to stage $(P=0.0003$; RR 4.44, 95\% CI 1.98-9.90) in adenocarcinoma cases (Table 2).

\section{Immunostaining of SPARC protein in lung cancer}

The expression of SPARC protein was examined in 162 primary lung cancers by immunostaining (Figure 3 ). In nonmalignant lung tissues, 73 of 128 cases (57\%), negative (0) to weak ( $1+$ ) SPARC expression was found in bronchial epithelial cell, while moderate $(2+)$ to very strong $(4+)$ expression was found in 55 cases. Alveolar cells were negative except for one case, which showed weak expression. Stromal fibroblasts distant from tumours showed negative to weak expression. Inflammatory cells including lymphocytes were negative expression, while chondrocytes of bronchial cartilage were moderate $(2+)$ to strong $(4+)$ SPARC expression. In 132 of 162 cases, negative $(0)$ to weak $(1+)$ SPARC expression was found in the cancer cells, while moderate $(2+)$ to strong $(4+)$ SPARC expression was found in 30 cases. Moderate
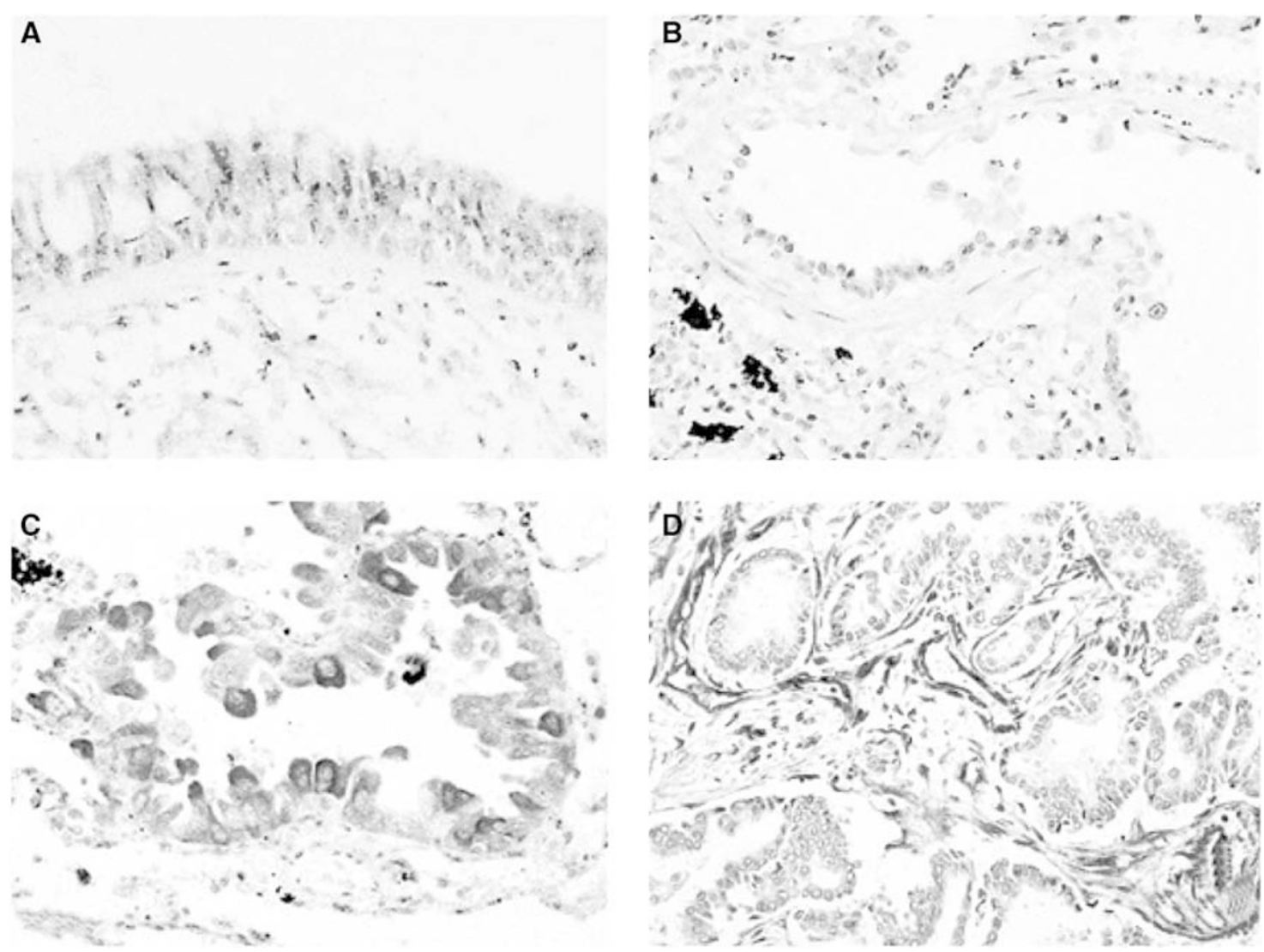

Figure 3 Immunostaining for SPARC in normal and malignant lung tissues. (A) Weak to moderate expression $(I-2+)$ of SPARC by bronchial epithelium. Most of the staining is present in the apical surface of ciliated surface cells. (B) Bronchioli showed negative (0) expression. (C) Strong ( + ) reactivity for SPARC in adenocarcinoma cells that lacked DNA methylation of SPARC gene, while alveolar cells and stromal cells are negative. (D) Negative immunostaining for SPARC in an adenocarcinoma demonstrating DNA methylation, while the adjacent stromal cells demonstrate very strong (4+) reactivity for SPARC; $\times 200$ magnification. 
$(2+)$ to very strong $(4+)$ SPARC expression was found in 154 of 162 cases in stromal cells near to or surrounding cancer cells. Thus, the predominant immunostaining pattern was negative in tumour cells while being positive in corresponding juxtatumoural

Table 3 (A) SPARC immunostaining in tumour and stromal cell $(n=162)$ and (B) methylation and immunostaining of SPARC in tumours $(n=162)$

\begin{tabular}{|c|c|c|c|}
\hline Tumour cell & Stromal cell & No. (\%) & $P$-value ${ }^{a}$ \\
\hline \multicolumn{4}{|l|}{ (A) } \\
\hline Positive & Positive $^{b}$ & $29(18)$ & $>0.9$ \\
\hline Positive & Negative $^{c}$ & I (I) & \\
\hline Negative & Positive & 125 (77) & \\
\hline Negative & Negative & $7(4)$ & \\
\hline Tumour methylation & Tumour immunostaining & No. (\%) & $P$-value \\
\hline \multicolumn{4}{|l|}{ (B) } \\
\hline Methylated & Positive & $11(7)$ & $<0.0001$ \\
\hline Methylated & Negative & $105(65)$ & \\
\hline Unmethylated & Positive & $19(12)$ & \\
\hline Unmethylated & Negative & $27(17)$ & \\
\hline Tumour methylation & Stromal immunostaining & No. (\%) & $P$-value \\
\hline Methylated & Positive & $110(68)$ & $>0.9$ \\
\hline Methylated & Negative & $6(4)$ & \\
\hline Unmethylated & Positive & $44(27)$ & \\
\hline Unmethylated & Negative & $2(1)$ & \\
\hline
\end{tabular}

SPARC $=$ secreted protein acidic and rich in cysteine. ${ }^{\text {a Fisher's exact probability }}$ bositive reveals moderate $(2+)$ to very strong $(4+)$ immunostaining. 'Negative reveals negative $(0)$ to weak $(1+)$ immunostaining. stromal cells (125 of $162,77 \%)$. However, there was no correlation of immunostaining pattern between tumour cells and stromal cells (Table 3A). Immunostaining pattern of neither tumour cells nor stromal cells correlated with patients' survival (data not shown). Of 162 cases, 105 showed loss $(0)$ or weak $(1+)$ expression of SPARC protein and methylation of SPARC gene, and 19 cases showed moderate $(2+)$ to very strong $(4+)$ expression without methylation (Table 3B). Thus, the concordance between methylation and loss of gene expression in tumour cells was $77 \%(P<0.0001)$. There was no correlation between tumour methylation and stromal cell immunostaining.

\section{DISCUSSION}

Sato et al demonstrated downregulation of SPARC mRNA in pancreatic cancer cells through DNA methylation (Sato et al, 2003). In our study, we observed that decreased SPARC expression in lung cancer cell lines is associated with DNA methylation of the gene promoter, and it is re-expressed by treatment with the demethylating agent 5-Aza-CdR in lung cancer cell lines. Although there are other possible mechanisms for downregulation of SPARC expression, the excellent concordance between mRNA expression by RT-PCR or protein expression by immunostaining and DNA methylation of SPARC indicates that the gene is downregulated mainly through DNA methylation in lung cancer.

As with other tumours, SPARC is downregulated in lung cancer cells while being upregulated in juxtatumoural stromal cells. Upregulation was unusual in stromal cells distant from the tumour. These findings result in a complex pattern of simultaneous selective downregulation in a specific cell type (tumour cells) accompanied by selective upregulation in adjacent stromal cells. A similar pattern has been previously described in ovarian, pancreatic, and lung cancers (Brown et al, 1999; Koukourakis et al,

Table 4 (A) Expression of SPARC in various tumours and (B) functional analyses of SPARC for tumorigenesis in tumour cell lines

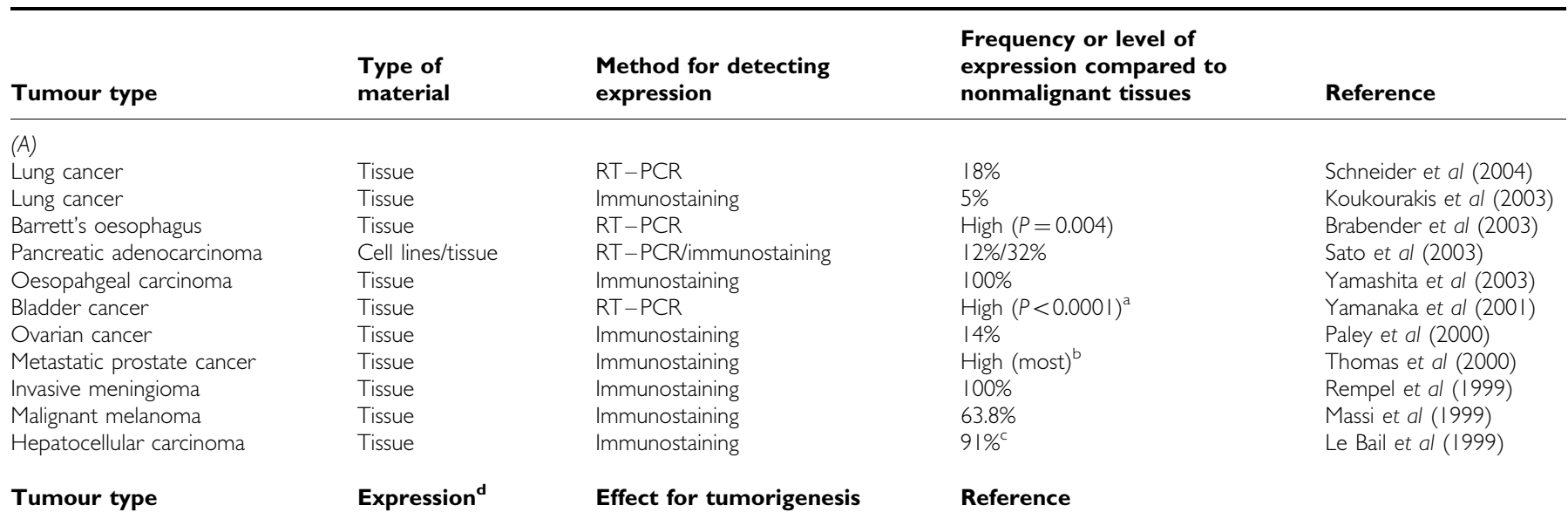

\begin{tabular}{|c|c|c|c|}
\hline \multicolumn{4}{|l|}{ (B) } \\
\hline \\
\hline \\
\hline \multicolumn{4}{|c|}{$\begin{array}{l}\text { Growth suppression } \\
\text { Promotion of cell migration } \\
\text { to bone } \\
\text { More rapid growth }\end{array}$} \\
\hline \multicolumn{4}{|c|}{$\begin{array}{l}\text { Growth suppression } \\
\text { Promotion of cell migration } \\
\text { to bone } \\
\text { More rapid growth } \\
\text { Impairing of tumour growth }\end{array}$} \\
\hline Breast cancer & High with c-Jun & $\begin{array}{l}\text { Increase of motility and } \\
\text { invasion }\end{array}$ & Briggs et al (2002) \\
\hline \multirow{2}{*}{$\begin{array}{l}\text { Glioma } \\
\text { Ovarian cancer }\end{array}$} & High & Promotion of invasion & Schultz et al (2002) \\
\hline & High & Inhibition of the proliferation & Yiu et al (200I) \\
\hline
\end{tabular}

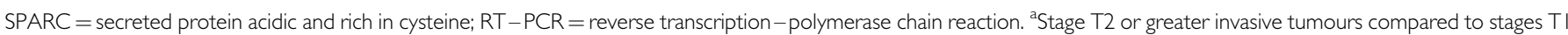

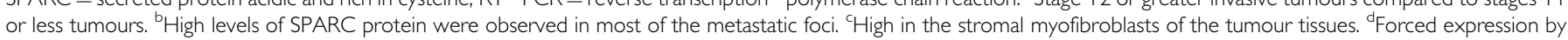
endogenous or exogenous SPARC. 
2003; Sato et al, 2003). Our findings demonstrate that the mechanism of downregulation of SPARC in lung cancer cells is due to methylation. The dual up- and downregulation of SPARC in tumours makes interpretation difficult, while its role in tumorigenesis remains controversial. SPARC may function similar to $\operatorname{TGF} \beta$, where signaling is downregulated in cancer cells early in tumorigenesis, but is overexpressed at later stages, thus acting either as tumour suppressor or oncogene, depending on the tumour stage (Wakefield and Roberts, 2002). Our data indicate that tumour-host interactions between lung cancer cells and stromal cells through SPARC protein play an important role in the pathogenesis of lung cancers.

Our data demonstrated that methylation of SPARC gene in tumour cells had poorer prognosis in lung adenocarcinomas, whereas reactivity of stromal fibroblasts had been reported to correlate worse prognosis in NSCLC (Koukourakis et al, 2003). The expression of SPARC in cancer tissues or functional analyses of SPARC gene in tumour cell lines have been widely studied (Table 4). Expression, as analysed by RT - PCR or immunostaining, was downregulated in lung, pancreatic, and ovarian cancers, whereas it was upregulated in oesophageal, bladder, metastatic prostate, hepatocellular cancers, and invasive meningiomas and malignant melanomas, and some of those findings were supported by functional analyses. The expression of SPARC by both normal and tumour cells is highly dependent on tumour type and culture conditions. Expression of SPARC in cancer tissues correlated with poor prognosis in malignant melanoma, bladder, and oesophageal carcinoma as also reported by others, although some of these reports was analysed by RT-PCR using whole specimens (Massi et al, 1999; Yamanaka et al, 2001; Yamashita et al, 2003). Aberrant expression of SPARC in primary tumours may result in negative prognosis.

In conclusion, SPARC was downregulated in cancer cells through DNA methylation and overexpressed in its stromal cells of lung cancer, and DNA methylation correlated with prognosis in adenocarcinomas. DNA methylation of $S P A R C$ may play a role in the pathogenesis of lung cancers.

\section{ACKNOWLEDGEMENTS}

This work was supported by a grant from the UT Specialized Program of Research Excellence in Lung Cancer (P50CA70907) and Early Detection Research Network, National Cancer Institute, Bethesda, MD, USA.

\section{REFERENCES}

Brabender J, Lord RV, Metzger R, Park J, Salonga D, Danenberg KD, Danenberg PV, Holscher AH, Schneider PM (2003) Differential SPARC mRNA expression in Barrett's oesophagus. Br J Cancer 89: $1508-1512$

Bradshaw AD, Sage EH (2001) SPARC, a matricellular protein that functions in cellular differentiation and tissue response to injury. J Clin Invest 107: 1049-1054

Brekken RA, Puolakkainen P, Graves DC, Workman G, Lubkin SR, Sage EH (2003) Enhanced growth of tumors in SPARC null mice is associated with changes in the ECM. J Clin Invest 111: 487-495

Brekken RA, Sage EH (2001) SPARC, a matricellular protein: at the crossroads of cell-matrix communication. Matrix Biol 19: 816-827

Briggs J, Chamboredon S, Castellazzi M, Kerry JA, Bos TJ (2002) Transcriptional upregulation of SPARC, in response to c-Jun overexpression, contributes to increased motility and invasion of MCF7 breast cancer cells. Oncogene 21: 7077-7091

Brown TJ, Shaw PA, Karp X, Huynh MH, Begley H, Ringuette MJ (1999) Activation of SPARC expression in reactive stroma associated with human epithelial ovarian cancer. Gynecol Oncol 75: 25-33

Chlenski A, Liu S, Crawford SE, Volpert OV, DeVries GH, Evangelista A, Yang Q, Salwen HR, Farrer R, Bray J, Cohn SL (2002) SPARC is a key Schwannian-derived inhibitor controlling neuroblastoma tumor angiogenesis. Cancer Res 62: 7357-7363

De S, Chen J, Narizhneva NV, Heston W, Brainard J, Sage EH, Byzova TV (2003) Molecular pathway for cancer metastasis to bone. J Biol Chem 278: $39044-39050$

Demopoulos K, Arvanitis DA, Vassilakis DA, Siafakas NM, Spandidos DA (2002) MYCL1, FHIT, SPARC, pl6(INK4) and TP53 genes associated to lung cancer in idiopathic pulmonary fibrosis. J Cell Mol Med 6: 215-222

Esteller M, Corn PG, Baylin SB, Herman JG (2001) A gene hypermethylation profile of human cancer. Cancer Res 61: 3225-3229

Everitt EA, Sage EH (1992a) Expression of SPARC is correlated with altered morphologies in transfected F9 embryonal carcinoma cells. Exp Cell Res 199: $134-146$

Everitt EA, Sage EH (1992b) Overexpression of SPARC in stably transfected F9 cells mediates attachment and spreading in $\mathrm{Ca}(2+)$-deficient medium. Biochem Cell Biol 70: 1368-1379

Girard L, Zochbauer-Muller S, Virmani AK, Gazdar AF, Minna JD (2000) Genome-wide allelotyping of lung cancer identifies new regions of allelic loss, differences between small cell lung cancer and non-small cell lung cancer, and loci clustering. Cancer Res 60: 4894-4906

Herman JG, Graff JR, Myohanen S, Nelkin BD, Baylin SB (1996) Methylation-specific PCR: a novel PCR assay for methylation status of CpG islands. Proc Natl Acad Sci USA 93: 9821-9826

Herrmann BG, Frischauf AM (1987) Isolation of genomic DNA. Methods Enzymol 152: 180 - 183

Jendraschak E, Sage EH (1996) Regulation of angiogenesis by SPARC and angiostatin: implications for tumor cell biology. Semin Cancer Biol 7: $139-146$

Jones PA, Baylin SB (2002) The fundamental role of epigenetic events in cancer. Nat Rev Genet 3: 415-428

Koukourakis MI, Giatromanolaki A, Brekken RA, Sivridis E, Gatter KC, Harris AL, Sage EH (2003) Enhanced expression of SPARC/osteonectin in the tumor-associated stroma of non-small cell lung cancer is correlated with markers of hypoxia/acidity and with poor prognosis of patients. Cancer Res 63: 5376-5380

Lane TF, Iruela-Arispe ML, Johnson RS, Sage EH (1994) SPARC is a source of copper-binding peptides that stimulate angiogenesis. J Cell Biol 125: 929-943

Lane TF, Sage EH (1994) The biology of SPARC, a protein that modulates cell-matrix interactions. FASEB J 8: $163-173$

Le Bail B, Faouzi S, Boussarie L, Guirouilh J, Blanc JF, Carles J, Bioulac-Sage P, Balabaud C, Rosenbaum J (1999) Osteonectin/SPARC is overexpressed in human hepatocellular carcinoma. J Pathol 189: 46-52

Ledda MF, Adris S, Bravo AI, Kairiyama C, Bover L, Chernajovsky Y, Mordoh J, Podhajcer OL (1997) Suppression of SPARC expression by antisense RNA abrogates the tumorigenicity of human melanoma cells. Nat Med 3: $171-176$

Massi D, Franchi A, Borgognoni L, Reali UM, Santucci M (1999) Osteonectin expression correlates with clinical outcome in thin cutaneous malignant melanomas. Hum Pathol 30: 339-344

Motamed K, Sage EH (1997) Regulation of vascular morphogenesis by the matricellular protein SPARC. Kidney Int 51: $1383-1387$

Paley PJ, Goff BA, Gown AM, Greer BE, Sage EH (2000) Alterations in SPARC and VEGF immunoreactivity in epithelial ovarian cancer. Gynecol Oncol 78: 336-341

Phelps RM, Johnson BE, Ihde DC, Gazdar AF, Carbone DP, McClintock PR, Linnoila RI, Matthews MJ, Bunn Jr PA, Carney D, Minna JD, Mulshine JL (1996) NCI-Navy Medical Oncology Branch cell line data base. J Cell Biochem Suppl 24: $32-91$

Porte H, Chastre E, Prevot S, Nordlinger B, Empereur S, Basset P, Chambon P, Gespach C (1995) Neoplastic progression of human colorectal cancer is associated with overexpression of the stromelysin-3 and BM-40/ SPARC genes. Int $J$ Cancer 64: 70-75

Rempel SA, Ge S, Gutierrez JA (1999) SPARC: a potential diagnostic marker of invasive meningiomas. Clin Cancer Res 5: 237-241

Sage EH (1997) Terms of attachment: SPARC and tumorigenesis. Nat Med 3: $144-146$ 
Sage H, Vernon RB, Funk SE, Everitt EA, Angello J (1989) SPARC, secreted protein associated with cellular proliferation, inhibits cell spreading in vitro and exhibits $\mathrm{Ca}^{+2}$-dependent binding to the extracellular matrix. J Cell Biol 109: 341-356

Sato N, Fukushima N, Maehara N, Matsubayashi H, Koopmann J, Su GH, Hruban RH, Goggins M (2003) SPARC/osteonectin is a frequent target for aberrant methylation in pancreatic adenocarcinoma and a mediator of tumor-stromal interactions. Oncogene 22: 5021-5030

Schneider S, Yochim J, Brabender J, Uchida K, Danenberg KD, Metzger R, Schneider PM, Salonga D, Holscher AH, Danenberg PV (2004) Osteopontin but not osteonectin messenger RNA expression is a prognostic marker in curatively resected non-small cell lung cancer. Clin Cancer Res 10: $1588-1596$

Schultz C, Lemke N, Ge S, Golembieski WA, Rempel SA (2002) Secreted protein acidic and rich in cysteine promotes glioma invasion and delays tumor growth in vivo. Cancer Res 62: 6270-6277

Suzuki M, Sunaga N, Shames DS, Toyooka S, Gazdar AF, Minna JD (2004) RNA interference-mediated knockdown of DNA methyltransferase 1 leads to promoter demethylation and gene re-expression in human lung and breast cancer cells. Cancer Res 64: 3137-3143
Thomas R, True LD, Bassuk JA, Lange PH, Vessella RL (2000) Differential expression of osteonectin/SPARC during human prostate cancer progression. Clin Cancer Res 6: 1140-1149

Toyooka S, Fukuyama Y, Wistuba II, Tockman MS, Minna JD, Gazdar AF (2002) Differential expression of FEZ1/LZTS1 gene in lung cancers and their cell cultures. Clin Cancer Res 8: 2292-2297

Wakefield LM, Roberts AB (2002) TGF-beta signaling: positive and negative effects on tumorigenesis. Curr Opin Genet Dev 12: $22-29$

Yamanaka M, Kanda K, Li NC, Fukumori T, Oka N, Kanayama HO, Kagawa S (2001) Analysis of the gene expression of SPARC and its prognostic value for bladder cancer. J Urol 166: 2495-2499

Yamashita K, Upadhay S, Mimori K, Inoue H, Mori M (2003) Clinical significance of secreted protein acidic and rich in cystein in esophageal carcinoma and its relation to carcinoma progression. Cancer 97: $2412-2419$

Yan Q, Sage EH (1999) SPARC, a matricellular glycoprotein with important biological functions. J Histochem Cytochem 47: 1495-1506

Yiu GK, Chan WY, Ng SW, Chan PS, Cheung KK, Berkowitz RS, Mok SC (2001) SPARC (secreted protein acidic and rich in cysteine) induces apoptosis in ovarian cancer cells. Am J Pathol 159: 609-622 


\section{Aberrant methylation of SPARC in human lung cancers}

M Suzuki, C Hao, T Takahashi, H Shigematsu, N Shivapurkar, U G Sathyanarayana, T lizasa, T Fujisawa, K Hiroshima and A F Gazdar

Retraction to: British Journal of Cancer (2005) 92, 942-948. doi:10.1038/sj.bjc.6602376

An Internal Review Committee at UT Southwestern Medical Center found evidence of improper replication of figures in this paper. A subsequent review by Dr Gazdar and his staff has independently confirmed the Committee's findings. In this paper, the GAPDH loading controls, specifically lanes 4-12 of Figure 1A and C ( $\mathrm{p}$ 944), appear to be identical. The authors have therefore recommended the retraction of the manuscript to the Editor-inChief of British Journal of Cancer.

Dr Suzuki, Dr Gazdar and their co-authors sincerely apologise for any inconvenience this may have caused the readers of the British Journal of Cancer. 